\title{
Experimental Study of NADPH- Diaphorase Positive Neurons in Nucleus Accumbens of Rats
}

\author{
Yan Zhao and Ke-Wei Huang
}

\begin{abstract}
Background: In order to explain the mechanism for the sparing of the nucleus accumbens in several pathologic conditions, the accumbens, caudate and putamen were examined in an experimental model. Methods: The neurons in these regions from twenty adult rats were stained for the enzyme nicotinamide adenine dinucleotide phosphate (NADPH-diaphorase) and quantified. Results: Positive neurons in the nucleus accumbens were more abundant than in the caudate and putamen. Conclusions: Since these neurons have been shown to be resistant to ischemia and degeneration, it is suggested that the mechanism for the sparing of the nucleus accumbens is related to the presence of a large number of NADPH-diaphorase positive neurons.
\end{abstract}

\begin{abstract}
RÉSUMÉ: Étude des neurones positifs pour la NADPH-diaphorase dans le noyau accumbens du rat. Introduction: Afin d'expliquer le mécanisme responsable de l'épargne sélective du noyau accumbens (Acc) dans plusieurs états pathologiques, nous avons examiné l'Acc, le noyau caudé et le putamen (Ca-Pu) d'un modèle expérimental. Méthodes: Nous avons coloré et quantifié les neurones de ces régions pour l'enzyme nicotinamide adénine dinucléotide phosphate diaphorase (NADPH-diaphorase) chez 20 rats adultes. Résultats: Les neurones positifs étaient plus nombreux dans l'Acc que dans le $\mathrm{Ca}-\mathrm{Pu}$, ce qui n'avait jamais été documenté antérieurement. Conclusions: Comme il est connu que ces neurones sont résistants à l'ischémie et à la dégénérescence, nous suggérons que l'épargne de l'Acc est due à la présence d'un grand nombre de neurones NADPH-diaphorase positifs.
\end{abstract}

Can. J. Neurol. Sci. 1995; 22: 294-296

It is well known that nucleus accumbens (Acc) is spared to a certain extent in Huntington's disease. ${ }^{1-3}$ We have found sparing of Acc in elderly and in anoxic encephalopathy patients (unpublished data) and believe it is likely related to biochemical resistance (pathoclisis) although the true mechanism by which Acc neurons are spared has not been determined. Uemura et al., $1989^{4}$ showed that NADPH-diaphorase-positive neurons were strikingly preserved in the dorsolateral portion of the gerbil striatum during ischemia, while there was severe loss of other neuronal types. Ferrante et al., $1985^{5}$ studied 6 cases of Huntington's disease and found sparing of NADPH-diaphorase-positive neurons along a $50-\mu \mathrm{m}$-wide track in the middle of the caudate nucleus, excluding the Acc. The above work shows that NADPH-diaphorase-positive neurons are resistant to ischemia and degeneration in Huntington's disease; here, we have investigated the number of NADPH-diaphorase-positive cells in the Acc, to see if a relative abundance of these cells could account for the sparing of Acc in elderly, anoxic encephalopathy and Huntington's patients.

\section{Materials and Methods}

Twenty adult Sprague-Dawley rats, weighing $290-450 \mathrm{~g}$ were used. The Acc and caudate putamen ( $\mathrm{Ca}-\mathrm{Pu})$ were identi- fied by the method of Paxinos and Watson. ${ }^{6}$ NADPH-diaphorase staining was performed by using a modification of the direct method of Uemura et al..$^{4}$ Brains were removed and immediately fixed in $10 \%$ neutral-buffered formalin for 24 at $4^{\circ} \mathrm{C}$ and then cryoprotected in $25 \%$ glycerol and $2 \%$ dimethylsulfoxide in 0.1 $\mathrm{M}$ phosphate buffer ( $\mathrm{pH} 7.3$ ) for 24 at $4^{\circ} \mathrm{C}$ prior to sectioning. The brains were cut into $50 \mu \mathrm{m}$-thick sections and incubated in a solution of $100 \mathrm{mg} / \mathrm{dl}$ nitroblue tetrazolium, $50 \mathrm{mg} / \mathrm{dl} \mathrm{NADPH}$ (type 1), $125 \mathrm{mg} / \mathrm{dl}$ monosodium malate, and $0.8 \%$ Triton $\mathrm{X}$ 100 (Sigma Labs, St. Louis, MO) in $0.1 \mathrm{M}$ phosphate buffer ( $\mathrm{pH}$ 8.0 ) at $37^{\circ} \mathrm{C}$. Sections were intermittently monitored for development, which took about $60-120$ minutes.

Counts of the NADPH-diaphorase positive neurons were made with a magnification of $200 \mathrm{X}$ in each field for both Acc and $\mathrm{Ca}-\mathrm{Pu}$ of the twenty rats. Ten fields were counted for each $\mathrm{Acc}$ and $\mathrm{Ca}-\mathrm{Pu}$ of every rat and standard deviations determined.

From the Neuropathology Laboratory, Chinese Pla General Hospital, Beijing. RECEIVED AUGUST 10, 1994. ACCEPTED IN FINAL FORM MAY 17, 1995.

Reprint requests to: Yan Zhoa, M.D., Neuropathology Laboratory, Chinese Pla General Hospital, Beijing, 100853 People's Republic of China 


\section{Results}

There were more numerous intensely stained NADPHdiaphorase-positive cellbodies in the Acc than in the Ca-Pu (Figure 1, Table). Furthermore, the density of NADPH-diaphorase-positive fibers was higher in the Acc than in Ca-Pu (Figure 2).

\section{Discussion}

Previous studies ${ }^{4.5 .7}$ have shown that nerve cells containing NADPH-diaphorase are resistant to various pathologic processes. Morton et al. ${ }^{8}$ studied five cases of Huntington's disease and five controls and found equally intense staining for NADPHdiaphorase through all regions of the neuropil in the striatum (Ca-Pu, Acc) of the controls. Ferrante et al. also investigated 12 patients with Huntington's disease and eight age-matched controls with NADPH-diaphorase staining. Although they found the density of NADPH-diaphorase neurons in Acc in controls was greater than in $\mathrm{Ca}-\mathrm{Pu}$, the difference did not reach statistical significance. Our experiment shows that NADPH-diaphorase-positive neurons are more abundant in the Acc than in the $\mathrm{Ca}-\mathrm{Pu}$ in rats, $(p>0.0001)$, results which are different from the above studies. One explanation for the difference is that the findings in normal animals are not valid in human studies. However, the Acc is a phylogenetically ancient extension of the head of the caudate, ${ }^{9}$ which most likely would undergo little change during

Table: The mean number of NADPH-diaphorase positive neurons (cell/fields).

\begin{tabular}{|c|c|c|c|c|c|c|c|}
\hline Rat's No. & $\begin{array}{c}\text { Acc } \\
\mathbf{x} 1\end{array}$ & $\begin{array}{c}\text { Ca-Pu } \\
\text { x }\end{array}$ & $x 1-x 2$ & Rat's No. & $\begin{array}{c}\text { Acc } \\
\mathrm{x} 1\end{array}$ & $\begin{array}{c}\text { Ca-Pu } \\
\text { x2 }\end{array}$ & $\mathrm{x} 1-\mathrm{x} 2$ \\
\hline 1 & 16.9 & 8.1 & 8.8 & 11 & 20.9 & 13.6 & 7.3 \\
\hline 2 & 14.1 & 7.8 & 6.3 & 12 & 21.0 & 7.7 & 13.3 \\
\hline 3 & 11.8 & 8.4 & 3.4 & 13 & 20.7 & 8.1 & 12.6 \\
\hline 4 & 17.8 & 7.7 & 10.1 & 14 & 15.1 & 8.8 & 6.3 \\
\hline 5 & 17.7 & 9.5 & 8.2 & 15 & 14.7 & 10.6 & 4.1 \\
\hline 6 & 17.6 & 7.6 & 10.0 & 16 & 18.4 & 10.0 & 8.4 \\
\hline 7 & 15.6 & 8.0 & 7.2 & 17 & 10.8 & 8.3 & 2.5 \\
\hline 8 & 12.4 & 5.9 & 6.5 & 18 & 20.4 & 8.6 & 11.8 \\
\hline 9 & 10.4 & 8.2 & 2.2 & 19 & 17.5 & 9.9 & 7.6 \\
\hline 10 & 22.4 & 14.2 & 8.2 & 20 & 12.1 & 8.4 & 3.7 \\
\hline
\end{tabular}

$\mathrm{t}=10.39 \mathrm{p}<0.001$
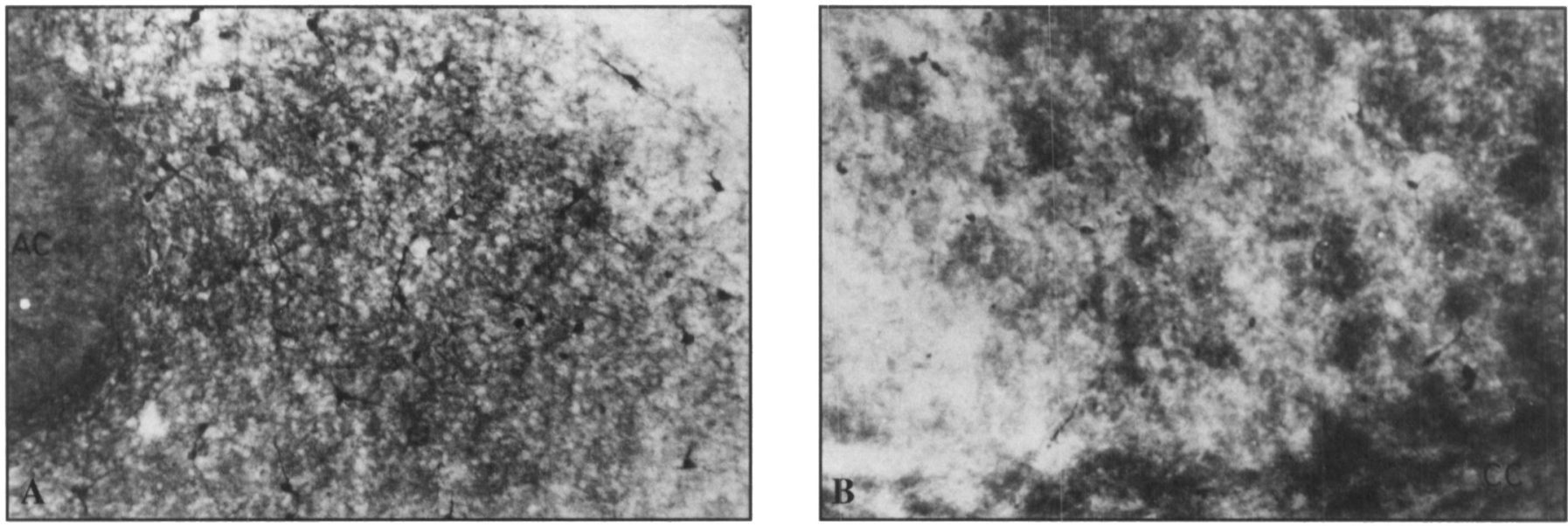

Figure I: Typical field showing larger numbers of NADPH-diaphorase positive neurons in nucleus accumbens (A) as compared with caudate and putamen (B). AC - Anterior commissure. CC - Corpus callosum. Magnification 100x.
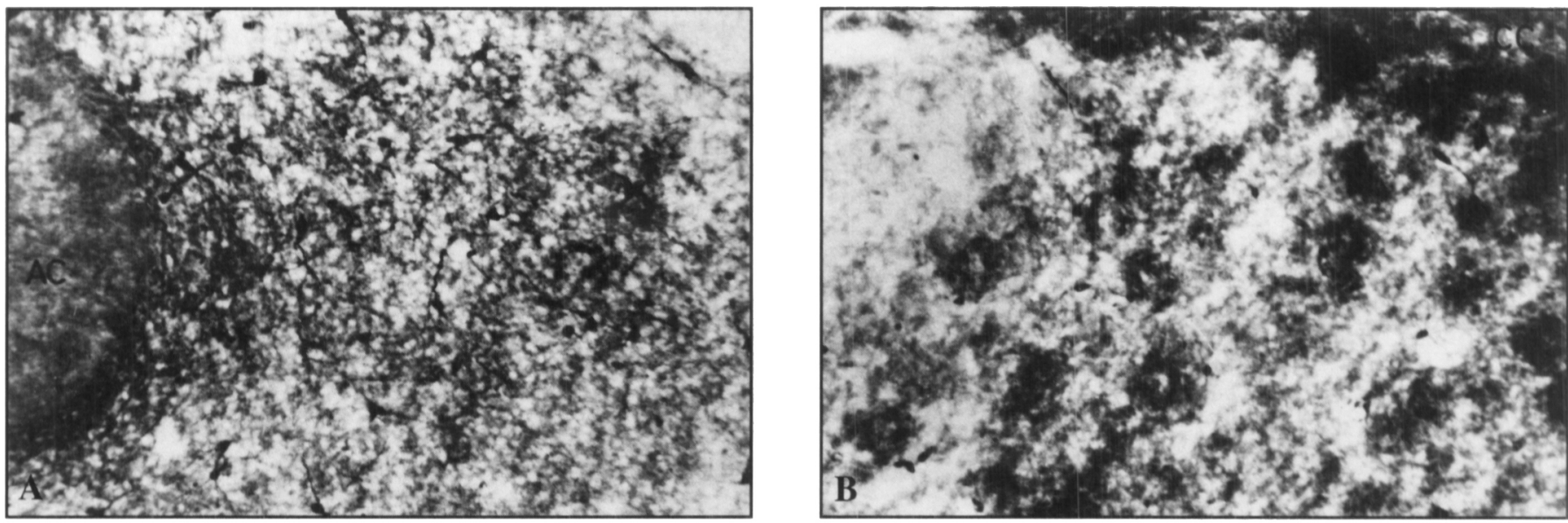

Figure 2: High density of NADPH-diaphorase positive fibers in the nucleus accumbens (A) as compared with the caudate and putamen (B). Magnification 400x. 
evolution. Another explanation is related to differences of morphometric methods in the counting of the positive NADPHdiaphorase neurons in normal controls. Confirmation of our data in human cases would suggest that the abundance of positive NADPH-diaphorase neurons in Acc may not only explain the sparing of this nucleus in Huntington's disease, but also the sparing of this nucleus in aging and anoxic encephalopathy. ${ }^{10}$

\section{ACKNOWLEDGEMENT}

This work was supported by Sandoz Foundation for Gerontological Research.

\section{REFERENCES}

1. McCaughey WTE. The pathological spectrum of Huntington's chorea. J Nerve Ment Dis 1961; 133; $91-103$

2. Bots GT, Bryun GW. Neuropathological change of nucleus accumbens in Huntington's chorea. Acta Neuropathol (Berl) 1981; 55; 21-22.
3. Bonasttel JP, Myers RH, Steven TJ, et al. Neuropathological classification of Huntington's disease. J Neuropathol Exp Neurol $1985 ; 44 ; 559-577$.

4. Uemura Y, Kowall NW, Beal MF. Selective sparing of NADPHdiaphorase-somatostatine-neuropeptide YU neurons in ischemic gerbil striatum. Ann Neurol 1989; 27; 620-625.

5. Ferrante RJ, Kowall NW, Beal MF, et al. Selective sparing of a class of striatal neurons in Huntington's disease. Science 1985; 561-563.

6. Paxinos $G$, Watson $C$. The rat brain in stereotaxic coordinates. 2nd Edition. Sydney: Academic Press, 1988; Figs. 10-13.

7. Unger JW, Lange W. NADPH-diaphorase-positive cell populations in the human amygdala and temporal cortex: neuroanatomy, peptidergic characteristics and aspects of aging and Alzheimer's disease. Acta Neuropathol 1992; 83: 636-646.

8. Morton AJ, Nicholson LFB, Faull RLM. Compartmental loss of NADPH-diaphorase in the neuropil of the human striatum in Huntington's disease. Neuroscience 1993; 58: 159-168.

9. Ariens-Kappers, Theunissen WF. Die Phylogenese des Rhinencephalons, des Corpus Striatum und Vorderhirn Kommissuren. Folia Neurobiol 1907: 173-288.

10. Huang $K-W$ and Zhao $Y$ (unpublished). Study on selective sparing of human nucleus accumbens to aging and anoxia. 